\title{
Surgical repair of an extracranial carotid aneurysm
}

\section{Tratamento cirúrgico de aneurisma da artéria carótida extracraniana}

\author{
Rodrigo Argenta', Stela Karine Braun ${ }^{1}$
}

\begin{abstract}
Aneurysms of the supra-aortic trunks are rare conditions that can cause peripheral neurological conditions or embolization resulting in stroke. The upper airways can even be affected and rupture is potentially fatal. We present a case of a patient with an aneurysm of the carotid bifurcation who was treated conventionally with reconstruction of the carotid bifurcation using a venous patch. Surgical treatment enabled accurate histopathological diagnosis and anatomic correction of the carotid bifurcation.
\end{abstract}

Keywords: carotid artery diseases; aneurysm; vascular surgical procedures.

\begin{abstract}
Resumo
Os aneurismas de troncos supra-aórticos são condições raras, que podem ocasionar alterações neurológicas periféricas ou embolizações com consequentes acidentes vasculares encefálicos. Também podem ocasionar alterações em vias aéreas superiores e sua ruptura é potencialmente fatal. Relatamos o caso de um paciente portador de aneurisma de artéria carótida no nível da bifurcação carotídea, tratado de forma convencional, com reconstrução da bifurcação com remendo venoso. $\mathrm{O}$ tratamento convencional dos aneurismas de troncos supra-aórticos permite o adequado diagnóstico histopatológico e a correção anatômica da bifurcação carotídea.
\end{abstract}

Palavras-chave: doenças das artérias carótidas; aneurisma; procedimentos cirúrgicos vasculares. 


\section{INTRODUCTION}

Supra-aortic trunk aneurysms are rare conditions, accounting for 0.4 to $4 \%$ of aneurysms. ${ }^{1}$ Occurrence of isolated aneurysms of the extracranial carotid artery is even rarer. ${ }^{2}$

The anatomic relationships between vessels, combined with progressive increase in aneurysm diameter, can lead to neurological conditions such as Horner syndrome and dislocation of the trachea with resulting dyspnea. ${ }^{3}$ Additionally, the habitual formation of thrombus within the aneurysm sac can cause embolization and stroke. These aneurysms rarely rupture. ${ }^{1}$

Although the etiology of these aneurysms includes connective tissue diseases, traumatisms and vasculitis, or can be congenital, they normally display histological similarities with degenerative aneurysms of the aorta. ${ }^{1}$

A range of surgical treatment techniques have been employed, ${ }^{4-7}$ in addition to endovascular options. ${ }^{2,8}$

\section{CASE REPORT}

The patient was a 65-year-old, white, male, ex-smoker with a history of systemic arterial hypertension who was referred to the hospital with a pulsating and painful mass on the right side of the neck which he said had been increasing in size for approximately 1 year. He was not suffering from dyspnea, but described a slight difficulty with deglutition.

After physical examination, a Doppler ultrasonography examination of the cervical region was conducted, finding an aneurysm involving the common carotid and right external carotid arteries. Additionally, angiotomography of the supra-aortic trunks confirmed the finding, showing a maximum diameter of $3.5 \mathrm{~cm}$ and a mural thrombus inside (Figure 1).

The patient was given general anesthesia for surgical treatment. Surgical access was achieved via an incision at the anterior margin of the right sternocleidomastoid muscle, and the common carotid (CC), internal carotid (IC) and external carotid (EC) arteries were repaired (Figure 2).

After full heparinization $(100 \mathrm{mg} / \mathrm{kg}$ of unfractionated heparin) and clamping of the arteries, the aneurysm was completely excised and flow to the internal carotid artery maintained by a temporary shunt between the CC and IC arteries (Figure 3).

Reconstruction of the carotid bifurcation was accomplished using a patch constructed from a

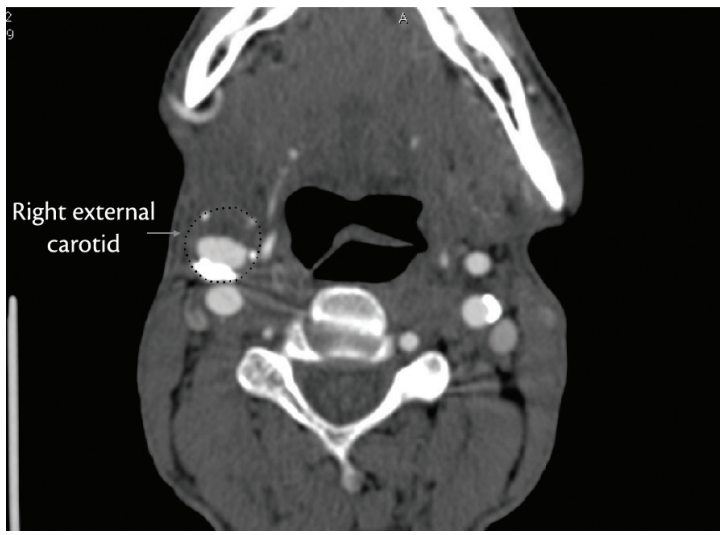

Figure 1. Angiotomography showing aneurysm of the right external carotid artery.



Figure 2. Surgical exposure of the branches of the common carotid.

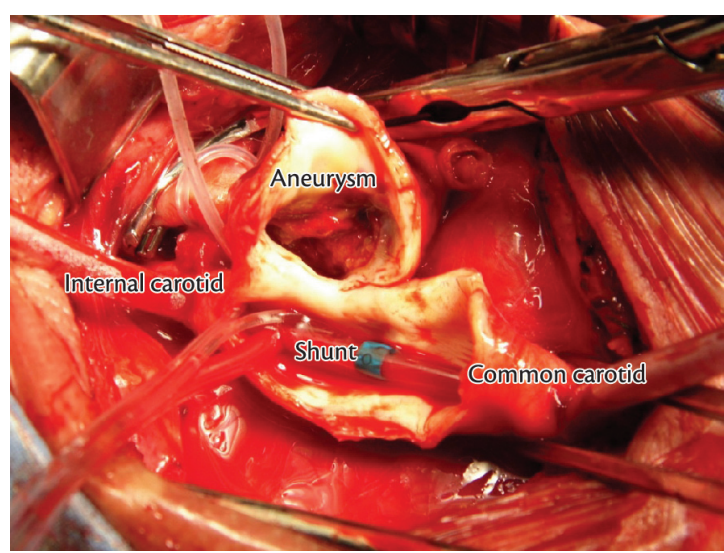

Figure 3. Resection of the aneurysm of the external carotid and creation of a shunt.

segment of the great saphenous vein from the right lower limb (Figure 4).

On the third day after surgery, the patient complained of precordial pain and was sent for coronary angiography, which did not show evidence of coronary stenoses. Carotid angiography was also conducted, confirming patency of the reconstructed 


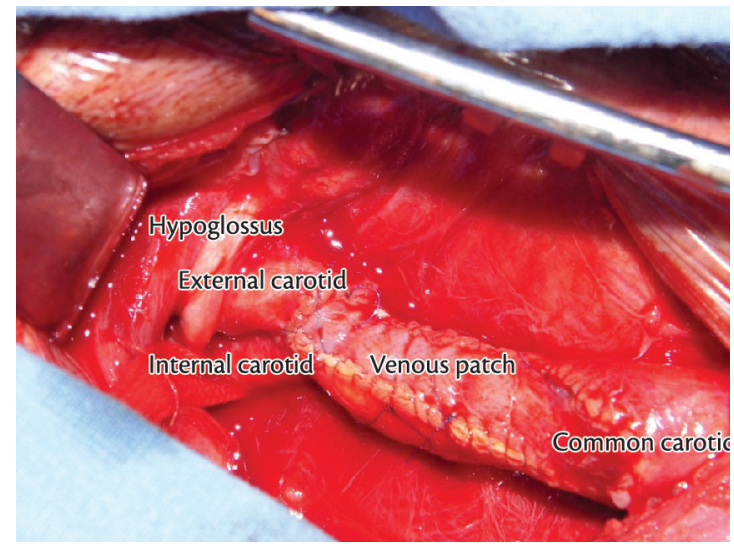

Figure 4. Bifurcation reconstructed with a great saphenous vein patch.

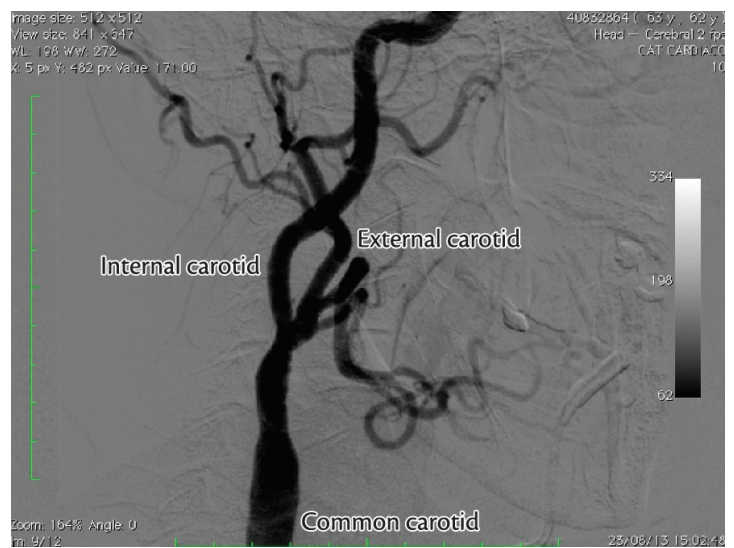

Figure 5. Post-reconstruction angiography.

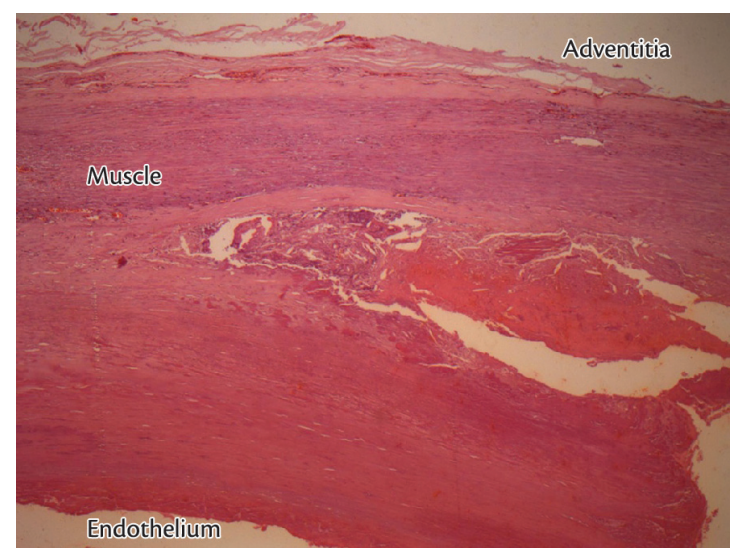

Figure 6. Histology - Hematoxylin eosin 5000x.

carotid bifurcation (Figure 5). The patient was discharged from hospital on the fifth day after surgery.

Histopathological analysis of the aneurysm confirmed atherosclerotic etiology (Figures 6 and 7).

At follow-up, 3 months after surgical repair, the patient reported being free from symptoms.

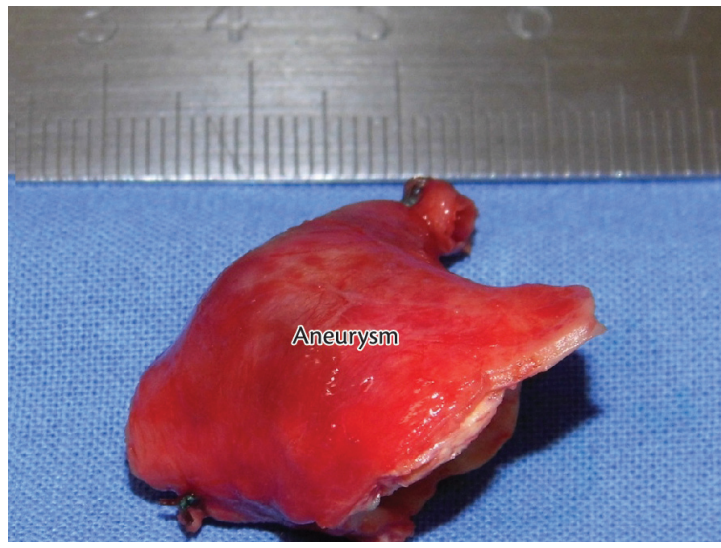

Figure 7. Macroscopy of aneurysm.

\section{DISCUSSION}

Aneurysms of the extracranial carotid artery are rare and their true incidence is unknown; however, the largest cases series that have been published allow for estimation of the probable incidence of these aneurysms at less than $1 \%$ of all diseases of the carotid artery., $3,6,9$ Causes can be degenerative and atherosclerotic, post-traumatic, post-endarterectomy, arterial dysplasia or may be related to infections, irradiation or cervical surgery. 7,8 Currently, atherosclerotic etiologies are most often reported, accounting for 40 to $70 \%$ of cases. ${ }^{10}$ These aneurysms tend to be fusiform and habitually involve the carotid bifurcation. ${ }^{10}$

Penetrating traumatic injuries to the cervical region can compromise the carotid artery in 12 to $17 \%$ of cases and a small number of these can develop pseudoaneurysms. ${ }^{11}$ The most common injury seen after blunt traumas is dissection. ${ }^{12}$

Post-endarterectomy aneurysms are among the most often reported. These develop as a result of failures at the suture line or failure of the material employed to create the patch. Patients normally exhibit phlogistic signs and in general infection of inorganic material is observed. ${ }^{10}$

Fibromuscular dysplasia has also been reported, with its typical "string-of-beads" appearance. ${ }^{13}$

As the diameter of the aneurysm increases, adjacent structures are compressed, causing localized symptoms, pain, dislocation of the trachea and esophagus and neurological involvement. Embolization can cause strokes and although rupture is rare, the consequences are devastating. ${ }^{3,14}$

In the case described here, the near-exclusive involvement of the external carotid artery and its posterior presentation allowed the aneurysm to reach a considerable diameter before any significant 
symptoms emerged. However, it is probable that had the progressive increase in diameter been allowed to continue, then the characteristic symptoms already mentioned would have occurred.

Delayed treatment of these aneurysms leads to technical difficulties ranging from exposure of affected structures to problems achieving vascular reconstruction. The favorable anatomic configuration and sufficient and safe exposure of structures allowed us to choose to maintain flow in the external carotid artery, in contrast with other authors who reported ligature of the vessel. ${ }^{15}$

Although the rapid developments in endovascular devices and techniques have widened their range of applications, ${ }^{2}$ in the context of aneurysmal disease with an intimate relationship with important structures of the neck, we do not believe that either stent-grafts or uncovered stents would be capable of resolving the problem of compression of adjacent structures. ${ }^{3}$ Additionally, surgical exposure enabled a complete anatomopathological diagnosis to be conducted.

Long-term results show an extremely low rate of recurrence of surgically repaired aneurysms, ${ }^{10}$ which further supports our belief that conventional surgery is the most appropriate option for treatment of this rare disease.

\section{REFERENCES}

1. Cury M, Greenberg RK, Morales JP, Mohabbat W, Hernandez AV. Supra-aortic vessels aneurysms: diagnosis and prompt intervention. J Vasc Surg. 2009;49(1):4-10. http://dx.doi. org/10.1016/j.jvs.2008.08.088. PMid:19174249

2. Hafner L, Almeida JA, Moreno JB, Uvo SAB, Nunes AP, Utida R, et al. Aneurisma da artéria carótida interna.J Vasc Bras. 2013;12(1):40-4. http://dx.doi.org/10.1590/S1677-54492013000100008.

3. Donato G, Giubbolini M, Chisci E, Setacci F, Setacci C. Giant external carotid aneurysm: A rare cause of dyspnoea, dysphagia and Horner's syndrome. EJVES Extra. 2006;11(2):19-22. http:// dx.doi.org/10.1016/j.ejvsextra.2005.10.003.

4. Jones WT, Pratt J, Connaughton J, Nichols S, Layton B, DuBose J. Management of a nontraumatic extracranial internal carotid aneurysm with external carotid transposition. J Vasc Surg. 2010;51(2):465-7. http://dx.doi.org/10.1016/j.jvs.2009.07.107. PMid:19782514

5. Papadopoulos N, Klein C, Ak K, Moritz A. Autologous repair of an internal carotid artery aneurysm by resection, caliber reduction, and external mesh tube reinforcement in a 9-year-old boy. J Vasc Surg. 2007;46(6):1280-2. http://dx.doi.org/10.1016/j. jvs.2007.07.036. PMid:18155007

6. Rosset E, Albertini JN, Magnan PE, Ede B, Thomassin JM, Branchereau A. Surgical treatment of extracranial internal carotid artery aneurysms. J Vasc Surg. 2000;31(4):713-23. http://dx.doi. org/10.1067/mva.2000.104102. PMid:10753279
7. De Luccia N, da Silva ES, Aponchik M, Appolonio F, Benvenuti LA. Congenital external carotid artery aneurysm. Ann Vasc Surg. 2010;24(3):418.e7-10. http://dx.doi.org/10.1016/j. avsg.2009.05.021. PMid:20036494

8. Gralla J, Remonda L, Schmidll J, Kohll S, Do DD, Schroth G. Mycotic aneurysm of the external carotid artery as a complication of bacterial endocarditis: Endovascular exclusion with an uncovered stent. EJVES Extra. 2004;8(2):37-8. http://dx.doi.org/10.1016/j. ejvsextra.2004.06.003.

9. McCollum CH, Wheeler WG, Noon GP, DeBakey ME. Aneurysms of the extracranial carotid artery. Twenty-one years' experience. Am J Surg. 1979;137(2):196-200. http://dx.doi.org/10.1016/00029610(79)90144-2. PMid:426176

10. El-Sabrout R, Cooley DA. Extracranial carotid artery aneurysms: Texas Heart Institute experience. J Vasc Surg. 2000;31(4):702-12. http://dx.doi.org/10.1067/mva.2000.104101. PMid:10753278

11. Rich NM, Baugh JH, Hughes CW. Acute arterial injuries in Vietnam: 1,000 cases. J Trauma. 1970;10(5):359-69. http://dx.doi. org/10.1097/00005373-197005000-00001. PMid:4909463

12. Biffl WL, Moore EE, Offner PJ, Brega KE, Franciose RJ, Burch JM. Blunt carotid arterial injuries: implications of a new grading scale. J Trauma. 1999;47(5):845-53. http://dx.doi.org/10.1097/00005373199911000-00004. PMid:10568710

13. Faggioli GL, Freyrie A, Stella A, Pedrini L, Gargiulo M, Tarantini $S$, et al. Extracranial internal carotid artery aneurysms: results of a surgical series with long-term follow-up. J Vasc Surg. 1996;23(4):587-94. http://dx.doi.org/10.1016/S07415214(96)80037-1. PMid:8627893

14. Hosoda K, Fujita S, Kawaguchi T, Shibata Y, Tamaki N. The use of an external-internal shunt in the treatment of extracranial internal carotid artery saccular aneurysms: technical case report. Surg Neurol. 1999;52(2):153-5. http://dx.doi.org/10.1016/S00903019(99)00039-7. PMid:10447282

15. Hertzer NR. Extracranial carotid aneurysms: a new look at an old problem. J Vasc Surg. 2000;31(4):823-5. http://dx.doi.org/10.1067/ mva.2000.105675. PMid:10753296

\section{Correspondence Rodrigo Argenta Avenida Dr. Nilo Peçanha 2825, sala 1304 CEP 91330-001 - Porto Alegre (RS), Brazil E-mail: argenta1976@gmail.com}

Author information RA is an MSc in Vascular Surgery from UFRGS, Preceptor of the Residence Program in Vascular and Endovascular Surgery, Hospital Nossa Senhora da Conceição. SKB is a resident physician in Endovascular Surgery, Hospital Nossa Senhora da Conceição.

Author contributions Conception and design: RA Analysis and interpretation: RA

Data collection: RA, SKB Writing the article: $R A$ Critical revision of the article: RA, SKB Final approval of the article*: RA, SKB Statistical analysis: N/A Overall responsibility: $R A$

*All authors have read and approved of the final version of the article submitted to J Vasc Bras. 